\title{
An in Vifro Study on Antifungal Properties, Total Polyphenolic Content and Antioxidant Activity of Different Parts of Selected Fruit Trees
}

\section{In vitro istraživanje protugljivičnih svojstava, ukupnog sadržaja polifenola i antioksidativne aktivnosti različitih dijelova odabranih voćkarica}

\author{
Original scientific paper • Izvorni znanstveni rad \\ Received-prispjelo: 4. 6. 2019. \\ Accepted-prihvaćeno: 15. 7. 2020. \\ UDK: $630 * 813.2 ; 630 * 841.513$ \\ https://doi.org/10.5552/drvind.2020.1934
}

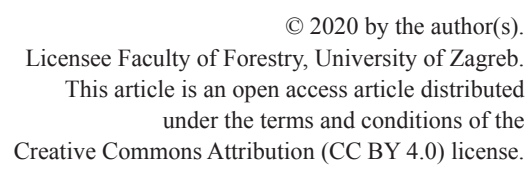

\begin{abstract}
The purpose of this study was to investigate the antifungal properties, total polyphenolic content and antioxidant activity of sapwood, heartwood and bark parts obtained from three different fruit trees; olive (Olea europaea L.), loquat (Eriobotrya japonica Lindl.) and date plum (Diospyros lotus L.) grown in Turkey. Firstly, the hydrodistillation products (essential oil, hydrosol, hot-water extract) were acquired from these parts of selected trees, and methanol and ethanol extracts of the same samples were also prepared for the analysis. The antifungal activities of essential oil, hydrosol, hot-water extract, ethanol and methanol extracts were determined against wood-rot fungus Coniophora puteana. In addition, polyphenol contents and antioxidant activities of ethanol and methanol extracts were investigated. According to the results, generally, the essential oil of the parts of three fruit trees was found to inhibit the fungal growth. All hot water extracts and hydrosols of these trees showed no antifungal activity against C. puteana. It was found that olive tree had higher antifungal activity than loquat and date plum trees. The methanol extract of loquat bark gave the highest total phenolic content, total flavonoid content and condensed tannin content compared to parts of the other trees. Furthermore, the highest total polyphenol content and antioxidant activity among three fruit trees were determined in ethanol and methanol extracts of the bark and heartwood of loquat tree. Based on these findings, it can be concluded that the parts of studied fruit trees have less or more antifungal and antioxidant activity depending on the experimental parameters, and therefore they can be evaluated as alternative natural antifungal and antioxidant sources.
\end{abstract}

Keywords: antioxidant; antifungal; bark; date plum; loquat; olive; wood

\footnotetext{
Authors are researchers at Karadeniz Technical University, Faculty of Forestry, Forest Industrial Engineering, Trabzon, Turkey.

${ }^{2}$ Author is researcher at Giresun University, Technical Sciences Vocational School, Architecture and Urban Planning Department, Giresun, Turkey.

${ }^{3}$ Trabzon University, School of Applied Sciences, Gastronomy and Culinary Arts, Trabzon, Turkey.
} 
SAŽETAK • Cilj ovog rada bio je istražiti protugljivična svojstva, ukupni sadržaj polifenola i antioksidativne aktivnosti bjeljike, srži i dijelova kore drva triju voćkarica koje se uzgajaju u Turskoj: masline (Olea europaea L.), nušpule (Eriobotrya japonica Lindl.) i draguna (Diospyros lotus L.). Najprije su od dijelova odabranih stabala izolirani produkti hidrodestilacije (esencijalna ulja, hidrosol, vodeni ekstrakt), a zatim su za analizu izolirani i ekstrakti u metanolu i etanolu. Protugljivična aktivnost esencijalnog ulja, hidrosola, vodenog ekstrakta te ekstrakata u metanolu i etanolu određena je na primjeru gljive uzročnice smeđe truleži, Coniophora puteana. Osim toga, istraženi su sadržaj polifenola i antioksidativna aktivnost ekstrakta u metanolu i etanolu. Rezultati pokazuju da esencijalna ulja iz dijelova voćkarica usporavaju rast gljiva. Svi vodeni ekstrakti i hidrosol nisu pokazali protugljivično djelovanje na C. puteana. Utvrđeno je da drvo masline ima jaču protugljivičnu aktivnost nego drvo nušpule $i$ drvo draguna. Ekstrakt kore nušpule u metanolu ima najveći ukupni sadržaj fenola, ukupni sadržaj flavonoida $i$ kondenziranog tanina u usporedbi s dijelovima ostalih vrsta drva. Nadalje, za ekstrakt kore $i$ srži drva nušpule u etanolu i metanolu utvrđen je najveći ukupni sadržaj polifenola i antioksidativna aktivnost od svih triju voćkarica. Na temelju tih rezultata može se zaključiti da dijelovi istraživanih voćkarica imaju manje ili više protugljivično i antioksidativno djelovanje, ovisno o parametrima istraživanja te se stoga mogu ocijeniti kao alternativni prirodni izvori protugljivičnih $i$ antioksidativnih sredstava.

Ključne riječi: antioksidativno sredstvo; protugljivično sredstvo; kora, dragun; nušpula; maslina; drvo

\section{INTRODUCTION}

\section{UVOD}

Turkey is characterized by great bioclimatic and geomorphological diversity, and is located at the intersection of three biogeographical regions (Euro-Siberian, Mediterranean and Irano-Turanian) (Noroozi et al., 2019). In Turkey, where forests cover $28.6 \%$ (22.3 million ha) of the land, about 75 fruit species, including 59 temperate zone and 16 subtropical fruit species are commercially grown (FAO, 2018). The main fruits produced in Turkey can be summarized as follows: olive, grape, bananas, kiwi, avocado, figs, pome fruits (apple, pears, medlar, quinces, loquats), citrus fruits (oranges, mandarin, lemons, grapefruits), stone fruits (peaches, plums, apricots, wild apricots, cherries, sour cherries, cornel, oleaster), nuts (almonds, hazelnuts, walnuts, chestnuts, pistachios), and other fruits such as mulberry, pomegranates, strawberries, persimmons, carobs, raspberry, blackberry, blueberry (TÜİK, 2018a).

Olive tree (Olea europaea L.) belongs to the Oleaceae family, which is a medium-sized family of approximately 25 genera and 688 species, and is a longlived evergreen tree. It is grown, both in the northern and southern hemispheres, between $30^{\circ}$ and $45^{\circ}$ latitude, in areas up to $2000 \mathrm{~m}$ high in Argentina, in areas below sea level in the Jordan Valley and Israel. Italy, Turkey, Greece, Spain, Cyprus, Portugal, Tunisia, Morocco, Syria, Algeria, France, Libya, former Yugoslavia, Egypt, Jordan and Israel produce about $97 \%$ of the world supply of olives today (CABI, 2019a). Olive tree is famous with its fruit and it has commercially important as the main source for the production of olive oil in the Mediterranean region (Ghanbari et al., 2012).. Turkey has a big potential for olive production and this production shows a tremendous increase every year. According to 2018 data, in Turkey, the total number of olive trees is $177,843.000$ and the total production including table olives and oil is 1,500.467 tons (TÜIK, 2018b).

Loquat (Eriobotrya japonica (Thunb.) Lindl.) belongs to the Rosaceae family, having 92 genera and 2,805 species of herbs, shrubs and trees, and it is a small evergreen tree that occasionally growing up to 10 meters. Loquat is indigenous to south-eastern China and Japan, and generally loquats are found between latitudes of $20^{\circ}$ and $35^{\circ}$ north and south. In addition, loquats are widely grown across India and South-East Asia, the Mediterranean region (particularly Spain and Turkey), the East Indies, Australia, New Zealand, South Africa and Madagascar (CABI, 2019b). Loquat has a high medicinal value and its various parts have been utilized as traditional medicine. In Chinese folk medicine, the extracts of loquat have been used for the cure of various illnesses such as chronic bronchitis, cough, diabetes, inflammation, and cancer (Liu et al., 2016). According to 2018 data, in Turkey, the total number of loquat trees, including bearing and nonbearing, is 285 thousand (TÜIK, 2018c).

Date plum (Diospyros lotus L.) is a deciduous tree that can grow up to 15 meters. It spreads from north Anatolia, Caucasia and Iran to Afghanistan, India, China and Japan (Mamıkoğlu, 2007). It has been proven that its fruit is a natural source of antioxidants (Gao et al., 2014) and exhibits hypoglycemic properties (Zhang et al., 2018) and anti-tumor-promoting activities (Rauf et al., 2016). In addition, all three fruit trees (olive, loquat and date plum) have diffuse-porous wood, paratracheal and apotracheal longitudinal parenchyma cells, and uniseriate and biseriate heterocellular rays (Topaloğlu et al., 2019).

As a result of the literature research, it was determined that the antifungal and antioxidant properties of leaves and fruits of the three fruit trees were investigated rather than wood properties of the trees. If these mentioned properties of stem wood and bark of these fruit trees are known, their potential use will increase in different areas. Therefore, the purposes of this study are:

- to determine the antifungal properties of ethanol and methanol extracts and hydrodistillation products such as essential oil, hydrosol and hot-water extract of sapwood, heartwood and bark of fruit trees,

- to determine the total polyphenol contents and antioxidant activity of ethanol and methanol extracts of sapwood, heartwood and bark of these trees. 


\section{MATERIALS AND METHODS \\ 2. MATERIJALI I METODE}

\subsection{Sample trees}

2.1. Uzorci drva

In this study, olive (Olea europaea L.), loquat (Eriobotrya japonica Lindl.) and date plum (Diospyros lotus L.) trees were taken as raw materials. A total of three trees of $30 \mathrm{~cm}$ in diameter and 45-50 years of age, with straight bole, no pests and diseases, and showing normal branching, were selected as the experiment materials. Olive and date plum trees were obtained from Artvin city, Yusufeli District $\left(40^{\circ} 53^{\prime}\right.$ north latitude $41^{\circ} 42^{\prime}$ east longitude) and loquat tree from Trabzon city, Arsin District ( $40^{\circ} 55^{\prime}$ north latitude - 39 $56^{\prime}$ east longitude) located in the Black Sea region of Turkey.

\subsection{Preparation of test samples}

2.2. Priprema ispitnih uzoraka

After harvesting, the logs were cut from these trees and barks were separated from these logs. These barks and logs were naturally air-dried. Then, each log was sawn into the boards having sapwood and heartwood. These samples were conditioned at $20^{\circ} \mathrm{C}$ temperature and $65 \%$ relative humidity until they reached to $12 \%$ moisture content. Air-dried particles of wood were grounded using a laboratory mill (Thomas-Wiley) screened and the samples stayed above 60 mesh were taken and prepared for analysis. All test samples were labeled as bark, sapwood and heartwood. Firstly, the hydrodistillation products (essential oil, hydrosol, hot water extract) of grounded samples were obtained in this study, and also ethanol and methanol extracts of the grounded samples were prepared.

\subsection{Hydrodistillation products}

\subsection{Produkti hidrodestilacije}

Water distillation method which is one of the hydrodistillation methods was used to obtain hydrodistillation products (essential oil, hydrosol, hot water extract) from grounded samples. Nearly $30 \mathrm{~g}$ of each grounded sample was taken and separately subjected to hydrodistillation process using a clevenger type apparatus for 3 hours according to the related method (Clevenger, 1928). After this process; essential oil, hydrosol, hot water extract products were obtained and stored at $-20{ }^{\circ} \mathrm{C}$ in amber vials before analysis. Essential oil, hydrosol, hot water extract of studied materials were used directly. It means the mentioned solutions were not extracted with any solvent.

\subsection{Ethanol and methanol extracts}

\subsection{Ekstrakti u etanolu i metanolu}

For extract preparation, about $5 \mathrm{~g}$ of grounded sample was taken and extracted seperately with $40 \mathrm{ml}$ of ethanol and methanol solvents. These were continuously stirred using a shaker (Heidolph, Promax 2020, Schwabach, Germany) for 24 hours. Particles in the mixtures were removed with filter paper (No.4, pore size 20-25 $\mu \mathrm{m}$ ) and solutions were filter-sterilized using $0.45 \mu \mathrm{m}$ hydrophilic polyvinylidene fluoride (PVDF) (Yildiz et al., 2018). A total of 18 ethanol and methanol extracts were prepared from sapwood, heartwood and bark of three fruit trees.

\subsection{Antifungal properties}

2.5. Protugljivična svojstva

In this study, antifungal properties of the samples obtained from sapwood, heartwood and bark of fruit trees were tested against brown rot fungus Coniophora puteana BAM Ebw. 15, according to the method mentioned in the study by Singh and Tripathi (1999). Firstly, malt extract agar solutions were prepared. Then, 15 $\mathrm{ml}$ of malt extract agar and $2 \mathrm{ml}$ of the studied materials (essential oil, hydrosol, hot-water extract, ethanol and methanol extract) were mixed in sterilized petri dishes, separately. After cooling, $5 \mathrm{~mm} \times 5 \mathrm{~mm}$ mycelium of $C$. puteana was added to the mixture in every petri dish. Then, all petri dishes were incubated at 22 $\pm 3{ }^{\circ} \mathrm{C}$ and $65 \pm 5 \%$ relative humidity. After that, the entire petri dish diameter (millimeter) and then the fungal mycelium diameter (millimeter) in petri dish were measured at the end of the $3^{\text {rd }}, 5^{\text {th }}$ and $7^{\text {th }}$ day using Digimizer Image Analysis Software program version 5.4.1. Fungal growth rate (\%) was calculated as a percentage ratio of the mycelium diameter to the entire petri dish diameter. All experiments were replicated three times.

\subsection{Total polyphenol content and antioxidant} activity

2.6. Ukupni sadržaj polifenola i antioksidativno djelovanje

In this study, total polyphenol content and antioxidant activity of ethanol and methanol extracts were investigated. Total polyphenol contents were determined by three different assays: total phenolic content (TPC), total flavonoid content (TFC) and condensed tannin content (CTC). Also, Ferric Reducing Antioxidant Power (FRAP) was tested as antioxidant activity.

\subsubsection{Determination of total polyphenol content}

2.6.1. Utvrđivanje ukupnog sadržaja polifenola

\subsubsection{Total phenolic content (TPC)}

Total phenolic content (TPC) measurements were made according to Folin-Ciocalteu method mentioned by Slinkard and Singleton (1977). This method briefly outlined as follows: $680 \mu \mathrm{L}$ distilled water, and $400 \mu \mathrm{l}$ Folin-Ciocalteu reagent $(0.5 \mathrm{~N}), 20 \mu \mathrm{l}$ various concentrations of gallic acid were prepared and mixed with samples in a tube and vortexed. After 3 min incubation, $400 \mu \mathrm{l} \mathrm{Na} \mathrm{CO}_{3} 10 \%$ (v/v) solution was added into the tube and vortexed again. Then, the mixture was incubated for 2 hours at $20^{\circ} \mathrm{C}$. After this incubation period, the absorbance of these sample mixtures was determined using an UV-VIS spectrophotometer at $760 \mathrm{~nm}$. The measurement results were expressed as mg gallic acid equivalents (GAE) per g dry weight of the sample.

\subsubsection{Total flavonoid content (TFC)} 2.6.1.2. Ukupni sadržaj flavonoida (TFC)

Total flavonoid content (TFC) measurements of the samples were performed according to the method 
previously reported by Fukumoto and Mazza (2000). In brief, $0.5 \mathrm{ml}$ sample, $0.1 \mathrm{ml} 10 \% \mathrm{Al}\left(\mathrm{NO}_{3}\right)_{3}$ and 0.1 $\mathrm{ml} 1 \mathrm{M} \mathrm{NH}_{4} \cdot \mathrm{CH}_{3} \mathrm{COO}$ were put into test tubes and incubated for $40 \mathrm{~min}$. at room temperature. Then, the absorbances of the samples were measured against a blank at $415 \mathrm{~nm}$. Results of this analysis were expressed as mg quercetin equivalents (QE) per g dry weight of the sample.

\subsubsection{Condensed tannin content (CTC)
2.6.1.3. Sadržaj kondenziranog tanina (CTC)}

Condensed tannin content (CTC) measurements of samples were carried out according to the method reported by Julkunen-Tiitto (1985). Before measurement, $750 \mu \mathrm{l} 4 \%$ vanillin (prepared with $\mathrm{MeOH}$ ) and various concentrations of $25 \mu \mathrm{l}$ from extracts of wood samples were mixed. After this step, $375 \mu$ concentrated $\mathrm{HCl}$ was added to the mixture. This solution was thoroughly mixed and then incubated for $20 \mathrm{~min}$ at room temperature under darkness condition. In this measurement, the absorbance of samples was read at $500 \mathrm{~nm}$ against a blank. In order to make the standard curve $(0.05-1 \mathrm{mg} / \mathrm{ml}),(+)$-catechin was used as standard. The analysis results were expressed as $\mathrm{mg}$ of catechin equivalent (CE)/g of dried sample.

\subsubsection{Antioxidant activity}

2.6.2. Antioksidativno djelovanje

2.6.2.1 Ferric reducing antioxidant power (FRAP)

2.6.2.1. Redukcijska antioksidativna snaga željeza (FRAP)

Ferric reducing antioxidant power (FRAP) assay of the samples was carried out as stated by Benzie and Strain (1996) with a slight modification. According to this method, the fresh FRAP reagent was prepared by using the mixture of $300 \mathrm{mM}$ acetate buffer ( $\mathrm{pH}$ 3.6) with $10 \mathrm{mM}$, TPTZ solution in $40 \mathrm{mM} \mathrm{HCl}$ and $20 \mathrm{mM}$ $\mathrm{FeCl}_{3} 6 \mathrm{H}_{2} \mathrm{O}$ solution. Also, 3ml FRAP reagent was mixed with $100 \mu \mathrm{l}$ samples and this mixture was incubated at $37^{\circ} \mathrm{C}$ for $4 \mathrm{~min}$. The absorbance of the sample was measured at $593 \mathrm{~nm}$ against reagent blank containing distilled water. $\mathrm{FeSO}_{4} \cdot 7 \mathrm{H}_{2} \mathrm{O}$ was used for measurement as positive control. FRAP values were determined as $\mu \mathrm{mol} \mathrm{FeSO}_{4} \cdot 7 \mathrm{H}_{2} \mathrm{O} \mathrm{g}^{-1}$ dry weight of the sample.

\subsection{Statistical analysis \\ 2.7. Statistička analiza}

Statistical analysis was performed using the SPSS 23.0 version. Analysis of variance (One-Way ANOVA) for all experimental parameters was performed on the basis of the $95 \%$ confidence interval. The mean and standard deviation values of each group were calculated. Duncan's homogeneity test was performed to determine significant differences among parameters.

\section{RESULTS AND DISCUSSION 3. REZULTATI I RASPRAVA}

\subsection{Antifungal activity}

3.1. Protugljivično djelovanje

Mean values of fungal growth rates (\%) of $C$. puteana on solutions of date plum tree parts in petri dishes are presented in Table 1.

Results showed that the essential oil and ethanol extract of both sapwood and heartwood of date plum tree, as well as the essential oil of date plum tree bark completely inhibited fungal growth of $C$. puteana at the end of the seventh day. Hot-water extract and hydrosol of sapwood, heartwood and bark of date plum tree did not show antifungal activity. It was also observed that the methanol extract of all three parts of date plum tree showed no anti-fungal activity after the third day. According to the results of One-Way ANOVA test, there were statistically significant differences between control and test samples $(P \leq 0.05)$, control

Table 1 Fungal growth rates of C. puteana on solutions of date plum tree parts in petri dishes (\%)

Tablica 1. Stupanj rasta gljive C. puteana na otopinama dijelova drva draguna u Petrijevim zdjelicama (\%)

\begin{tabular}{|c|c|c|c|c|}
\hline $\begin{array}{c}\text { Tree parts } \\
\text { Dijelovi drva }\end{array}$ & $\begin{array}{l}\text { Solutions } \\
\text { Otopina }\end{array}$ & $\begin{array}{l}\mathbf{3}^{\text {rd }} \text { day } \\
\text { Treći dan }\end{array}$ & $\begin{array}{c}\mathbf{5}^{\text {th }} \text { day } \\
\text { Peti dan }\end{array}$ & $\begin{array}{c}7^{\text {th }} \text { day } \\
\text { Sedmi dan }\end{array}$ \\
\hline \multirow{5}{*}{$\begin{array}{l}\text { Sapwood of date plum tree } \\
\text { bjeljika drva draguna }\end{array}$} & Hot-water extract / vodeni ekstrakt & $7.52(1.80)^{\mathrm{cd}}$ & $52.49(8.13)^{\mathrm{e}}$ & $100.00(0.00)^{\mathrm{f}}$ \\
\hline & Hydrosol / hidrosol & $8.89(2.62)^{\mathrm{d}}$ & $49.51(6.21)^{\mathrm{e}}$ & $100.00(0.00)^{\mathrm{f}}$ \\
\hline & Methanol extract / ekstrakt u metanolu & $0.00(0.00)^{\mathrm{a}}$ & $8.30(0.42)^{\mathrm{b}}$ & $12.35(0.49)^{\mathrm{c}}$ \\
\hline & Ethanol extract / ekstrakt $u$ etanolu & $0.00(0.00)^{\mathrm{a}}$ & $0.00(0.00)^{\mathrm{a}}$ & $0.00(0.00)^{\mathrm{a}}$ \\
\hline & Essential oil / esencijalno ulje & $0.00(0.00)^{\mathrm{a}}$ & $0.00(0.00)^{\mathrm{a}}$ & $0.00(0.00)^{\mathrm{a}}$ \\
\hline \multirow{5}{*}{$\begin{array}{l}\text { Heartwood of date plum tree } \\
\text { srž drva draguna }\end{array}$} & Hot-water extract / vodeni ekstrakt & $7.91(1.24)^{\mathrm{d}}$ & $64.58(9.03)^{\mathrm{f}}$ & $100.00(0.00)^{\mathrm{f}}$ \\
\hline & Hydrosol / hidrosol & $8.26(0.25)^{\mathrm{d}}$ & $54.21(5.67)^{\mathrm{e}}$ & $100.00(0.00)^{\mathrm{f}}$ \\
\hline & Methanol extract / ekstrakt u metanolu & $0.00(0.00)^{\mathrm{a}}$ & $10.91(1.28)^{\mathrm{bc}}$ & $21.75(1.76)^{\mathrm{d}}$ \\
\hline & Ethanol extract / ekstrakt $u$ etanolu & $0.00(0.00)^{\mathrm{a}}$ & $0.00(0.00)^{\mathrm{a}}$ & $0.00(0.00)^{\mathrm{a}}$ \\
\hline & Essential oil / esencijalno ulje & $0.00(0.00)^{\mathrm{a}}$ & $0.00(0.00)^{\mathrm{a}}$ & $0.00(0.00)^{\mathrm{a}}$ \\
\hline \multirow{5}{*}{$\begin{array}{l}\text { Bark of date plum tree } \\
\text { kora drva draguna }\end{array}$} & Hot-water extract / vodeni ekstrakt & $6.23(0.03)^{\mathrm{c}}$ & $37.11(5.25)^{\mathrm{d}}$ & $57.42(4.97)^{\mathrm{e}}$ \\
\hline & Hydrosol / hidrosol & $3.11(1.41)^{b}$ & $16.70(3.42)^{\mathrm{c}}$ & $58.74(5.07)^{\mathrm{e}}$ \\
\hline & Methanol extract / ekstrakt u metanolu & $0.00(0.00)^{\mathrm{a}}$ & $1.37(0.28)^{\mathrm{a}}$ & $8.53(0.37)^{\mathrm{b}}$ \\
\hline & Ethanol extract / ekstrakt $u$ etanolu & $0.00(0.00)^{\mathrm{a}}$ & $1.09(0.12)^{\mathrm{a}}$ & $3.32(0.28)^{\mathrm{a}}$ \\
\hline & Essential oil / esencijalno ulje & $0.00(0.00)^{\mathrm{a}}$ & $0.00(0.00)^{\mathrm{a}}$ & $0.00(0.00)^{\mathrm{a}}$ \\
\hline Control / kontrolni uzorci & & $11.41(0.58)^{\mathrm{e}}$ & $67.28(1.81)^{\mathrm{f}}$ & $100.00(0.00)^{\mathrm{f}}$ \\
\hline
\end{tabular}

Values in parenthesis are standard deviations. Different superscript letters in the same column indicate significant difference by Duncan's homogeneity test, $P \leq 0.05$. / Vrijednosti u zagradama standardne su devijacije. Različita slova u eksponentu u istom stupcu upućuju na značajnu razliku utvrđenu Duncanovim testom, $P \leq 0,05$. 
.. Ustaömer, Topaloğlu, Yilmaz, Serencam, Deniz: An in Vitro Study on Antifungal Properties...

Table 2 Fungal growth rates of C. puteana on solutions of loquat tree parts in petri dishes (\%)

Tablica 2. Stupanj rasta gljive C. puteana na otopinama dijelova drva nušpule u Petrijevim zdjelicama (\%)

\begin{tabular}{|c|c|c|c|c|}
\hline $\begin{array}{c}\text { Tree parts } \\
\text { Dijelovi drva }\end{array}$ & $\begin{array}{c}\text { Solutions } \\
\text { Otopina }\end{array}$ & $\begin{array}{l}\mathbf{3}^{\text {rd }} \text { day } \\
\text { Treći dan }\end{array}$ & $\begin{array}{c}\mathbf{5}^{\text {th }} \text { day } \\
\text { Peti dan }\end{array}$ & $\begin{array}{c}7^{\text {th }} \text { day } \\
\text { Sedmi dan }\end{array}$ \\
\hline \multirow{5}{*}{$\begin{array}{l}\text { Sapwood of loquat tree } \\
\text { bjeljika drva nušpule }\end{array}$} & Hot-water extract / vodeni ekstrakt & $8.15(2.83)^{\mathrm{e}}$ & $57.42(4.97)^{\mathrm{e}}$ & $100.00(0.00)^{g}$ \\
\hline & Hydrosol / hidrosol & $7.89(1.27)^{\mathrm{de}}$ & $59.77(1.66)^{\mathrm{e}}$ & $100.00(0.00)^{g}$ \\
\hline & Methanol extract / ekstrakt u metanolu & $0.00(0.00)^{\mathrm{a}}$ & $0.00(0.00)^{\mathrm{a}}$ & $0.00(0.00)^{\mathrm{a}}$ \\
\hline & Ethanol extract / ekstrakt $u$ etanolu & $0.00(0.00)^{\mathrm{a}}$ & $1.98(0.03)^{\mathrm{a}}$ & $16.88(2.65)^{\mathrm{c}}$ \\
\hline & Essential oil / esencijalno ulje & $0.00(0.00)^{\mathrm{a}}$ & $45.63(2.31)^{\mathrm{d}}$ & $54.13(3.01)^{\mathrm{d}}$ \\
\hline \multirow{5}{*}{$\begin{array}{l}\text { Heartwood of loquat tree } \\
\text { srž drva nušpule }\end{array}$} & Hot-water extract / vodeni ekstrakt & $9.07(0.39)^{\mathrm{e}}$ & $74.65(6.57)^{\mathrm{g}}$ & $100.00(0.00)^{\mathrm{g}}$ \\
\hline & Hydrosol / hidrosol & $4.39(0.41)^{\mathrm{b}}$ & $34.55(3.61)^{\mathrm{bc}}$ & $59.77(1.66)^{\mathrm{e}}$ \\
\hline & Methanol extract / ekstrakt u metanolu & $0.00(0.00)^{\mathrm{a}}$ & $2.05(0.98)^{\mathrm{a}}$ & $15.03(1.37)^{\mathrm{c}}$ \\
\hline & Ethanol extract / ekstrakt $u$ etanolu & $0.00(0.00)^{\mathrm{a}}$ & $0.00(0.00)^{\mathrm{a}}$ & $0.00(0.00)^{\mathrm{a}}$ \\
\hline & Essential oil / esencijalno ulje & $0.00(0.00)^{\mathrm{a}}$ & $0.00(0.00)^{\mathrm{a}}$ & $0.00(0.00)^{\mathrm{a}}$ \\
\hline \multirow{5}{*}{$\begin{array}{l}\text { Bark of loquat tree } \\
\text { kora drva nušpule }\end{array}$} & Hot-water extract / vodeni ekstrakt & $6.19(1.68)^{\mathrm{c}}$ & $29.79(3.12)^{\mathrm{b}}$ & $87.95(0.08)^{\mathrm{f}}$ \\
\hline & Hydrosol / hidrosol & $6.33(0.99)^{\mathrm{cd}}$ & $38.67(6.08)^{\mathrm{c}}$ & $55.73(0.59)^{\mathrm{d}}$ \\
\hline & Methanol extract / ekstrakt u metanolu & $0.00(0.00)^{\mathrm{a}}$ & $1.20(0.29)^{\mathrm{a}}$ & $10.37(0.52)^{\mathrm{b}}$ \\
\hline & Ethanol extract / ekstrakt $u$ etanolu & $0.00(0.00)^{\mathrm{a}}$ & $0.00(0.00)^{\mathrm{a}}$ & $0.00(0.00)^{\mathrm{a}}$ \\
\hline & Essential oil / esencijalno ulje & $0.00(0.00)^{\mathrm{a}}$ & $0.00(0.00)^{\mathrm{a}}$ & $0.00(0.00)^{\mathrm{a}}$ \\
\hline Control / kontrolni uzorci & & $11.41(0.58)^{\mathrm{f}}$ & $67.28(1.81)^{\mathrm{f}}$ & $100.00(0.00)^{\mathrm{g}}$ \\
\hline
\end{tabular}

Values in parenthesis are standard deviations. Different superscript letters in the same column indicate significant difference by Duncan's homogeneity test, $P \leq 0.05$. / Vrijednosti u zagradama standardne su devijacije. Različita slova u eksponentu u istom stupcu upućuju na značajnu razliku utvrđenu Duncanovim testom, $P \leq 0,05$.

Table 3 Fungal growth rates of C. puteana on solutions of olive tree parts in petri dishes (\%)

Tablica 3. Stupanj rasta gljive C. puteana na otopinama dijelova drva masline u Petrijevim zdjelicama (\%)

\begin{tabular}{|c|c|c|c|c|}
\hline $\begin{array}{c}\text { Tree parts } \\
\text { Dijelovi drva }\end{array}$ & $\begin{array}{l}\text { Solutions } \\
\text { Otopina }\end{array}$ & $\begin{array}{l}\mathbf{3}^{\text {rd }} \text { day } \\
\text { Treći dan }\end{array}$ & $\begin{array}{l}\mathbf{5}^{\text {th }} \text { day } \\
\text { Peti dan }\end{array}$ & $\begin{array}{c}\mathbf{7}^{\text {th }} \text { day } \\
\text { Sedmi dan }\end{array}$ \\
\hline \multirow{5}{*}{$\begin{array}{l}\text { Sapwood of olive tree } \\
\text { bjeljika drva masline }\end{array}$} & Hot-water extract / vodeni ekstrakt & $8.14(2.73)^{\mathrm{c}}$ & $42.01(1.40)^{\mathrm{de}}$ & $100.00(0.00)^{\mathrm{d}}$ \\
\hline & Hydrosol / hidrosol & $8.65(3.54)^{\mathrm{c}}$ & $36.62(4.56)^{\mathrm{c}}$ & $100.00(0.00)^{\mathrm{d}}$ \\
\hline & Methanol extract / ekstrakt u metanolu & $0.00(0.00)^{\mathrm{a}}$ & $0.00(0.00)^{\mathrm{a}}$ & $2.78(1.04)^{\mathrm{a}}$ \\
\hline & Ethanol extract / ekstrakt u etanolu & $0.00(0.00)^{\mathrm{a}}$ & $0.00(0.00)^{\mathrm{a}}$ & $0.00(0.00)^{\mathrm{a}}$ \\
\hline & Essential oil / esencijalno ulje & $0.00(0.00)^{\mathrm{a}}$ & $0.00(0.00)^{\mathrm{a}}$ & $0.00(0.00)^{\mathrm{a}}$ \\
\hline \multirow{5}{*}{$\begin{array}{l}\text { Heartwood of olive tree } \\
\text { srž drva masline }\end{array}$} & Hot-water extract / vodeni ekstrakt & $7.68(1.57)^{\mathrm{c}}$ & $39.26(8.29)^{\text {cd }}$ & $100.00(0.00)^{\mathrm{d}}$ \\
\hline & Hydrosol / hidrosol & $4.88(0.72)^{\mathrm{b}}$ & $56.10(6.84)^{\mathrm{f}}$ & $100.00(0.00)^{\mathrm{d}}$ \\
\hline & Methanol extract / ekstrakt u metanolu & $0.00(0.00)^{\mathrm{a}}$ & $0.00(0.00)^{\mathrm{a}}$ & $0.00(0.00)^{\mathrm{a}}$ \\
\hline & Ethanol extract / ekstrakt u etanolu & $0.00(0.00)^{\mathrm{a}}$ & $0.00(0.00)^{\mathrm{a}}$ & $0.00(0.00)^{\mathrm{a}}$ \\
\hline & Essential oil / esencijalno ulje & $0.00(0.00)^{\mathrm{a}}$ & $0.00(0.00)^{\mathrm{a}}$ & $0.00(0.00)^{\mathrm{a}}$ \\
\hline \multirow{5}{*}{$\begin{array}{l}\text { Bark of olive tree } \\
\text { kora drva masline }\end{array}$} & Hot-water extract / vodeni ekstrakt & $1.46(1.02)^{\mathrm{a}}$ & $26.56(2.21)^{\mathrm{b}}$ & $38.72(4.90)^{\mathrm{b}}$ \\
\hline & Hydrosol / hidrosol & $5.47(0.97)^{\mathrm{b}}$ & $46.13(1.60)^{\mathrm{e}}$ & $66.02(7.18)^{\mathrm{c}}$ \\
\hline & Methanol extract / ekstrakt u metanolu & $0.00(0.00)^{\mathrm{a}}$ & $0.00(0.00)^{\mathrm{a}}$ & $0.00(0.00)^{\mathrm{a}}$ \\
\hline & Ethanol extract / ekstrakt u etanolu & $0.00(0.00)^{\mathrm{a}}$ & $0.00(0.00)^{\mathrm{a}}$ & $0.00(0.00)^{\mathrm{a}}$ \\
\hline & Essential oil / esencijalno ulje & $0.00(0.00)^{\mathrm{a}}$ & $0.00(0.00)^{\mathrm{a}}$ & $0.00(0.00)^{\mathrm{a}}$ \\
\hline Control / kontrolni uzorci & & $11.41(0.58)^{\mathrm{d}}$ & $67.28(1.81)^{\mathrm{g}}$ & $100.00(0.00)^{\mathrm{d}}$ \\
\hline
\end{tabular}

Values in parenthesis are standard deviations. Different superscript letters in the same column indicate significant difference by Duncan's homogeneity test, $P \leq 0.05$. / Vrijednosti u zagradama standardne su devijacije. Različita slova u eksponentu u istom stupcu upućuju na značajnu razliku utvrđenu Duncanovim testom, $P \leq 0,05$.

samples exhibiting higher fungal growth rates than test samples, especially at the end of the fifth day. According to our results presented in Table 1, the stem wood and bark of date plum have antifungal activity. As a result of the literature research, it was determined that the bioactive properties of fruits, leaves and roots of date plum tree were investigated, while those of stem wood were not. Uddin et al. (2013) investigated antimicrobial activities of extracted oil of $D$. lotus roots and Uddin et al. (2014) examined anti-nociceptive, anti-inflammatory and sedative activities of the extracts of $D$. lotus roots.

Mean values of fungal growth rates (\%) of $C$. puteana on solutions of loquat tree parts in petri dishes are presented in Table 2.

The ethanol extract and essential oil of both heartwood and bark of loquat tree, as well as methanol extract of sapwood of loquat tree completely inhibited fungal growth of $C$. puteana at the end of the seventh day. The hydrosol and hot-water extract of sapwood, 
heartwood and bark of loquat tree did not show antifungal activity. Methanol extract of heartwood and bark of loquat tree showed no antifungal activity after the third day. According to the results of One-Way ANOVA test, there were statistically significant differences between control and test samples $(P \leq 0.05)$. The hot-water extract of heartwood of loquat tree, which had the highest growth rate, was the most ineffective against $C$. puteana, especially compared to the control sample on the fifth day.

Mean values of fungal growth rates (\%) of $C$. puteana on solutions of olive tree parts in petri dishes are given in Table 3 .

Results showed that the ethanol and methanol extracts and the essential oil of heartwood and bark of olive tree, as well as the essential oil and ethanol extract of sapwood of olive tree had the best antifungal activity by completely inhibiting fungal growth of $C$. puteana. Methanol extract of sapwood of olive tree extract did not entirely prevent the fungal growth. Hot-water and hydrosol of all three parts of olive tree showed no antifungal activity against $C$. puteana at the end of the seventh day. After evaluating the results of antifungal activities obtained in this study for all three fruit trees species, it can be concluded that, generally, all three parts of olive tree showed better antifungal activity compared to loquat and date plum wood species.

There are many studies in the literature related to the antifungal activity of different parts of various wood species against wood-rot fungi. Fidah et al. (2016) studied the antifungal activity of Cedrus atlantica essential oil against four wood-decaying fungi (Gloeophyllum trabeum, Oligoporus placenta, Coniophora puteana and Trametes versicolor). They found that the essential oil of Cedrus atlantica sawdust had important antifungal activity against the four wooddestroying fungi. Mihara et al. (2005) found that the methanol extracts of Acacia auriculiformis showed strong antifungal effects on the growth of wood rotting fungi (Phellinus noxius and Phellinus badius), while the extracts of Acacia mangium had no effect on the growth of Phellinus noxius and little inhibition of Phellinus badius. Ateş et al. (2015) examined the antifungal activities of different parts of juniper (Juniperus foetidissima) and olive (Olea europaea var. sylvestris) wood against Pleurotus ostreatus mycelium. They found that the extractives (concentration of $500 \mathrm{ppm}$ ) of heartwood and sapwood of juniper and olive inhibited $(80 \%)$ the growth of Pleurotus ostreatus mycelium. Tümen et al. (2013), determined the antifungal activity of hexane and ethanol extracts of heartwood samples of three Juniperus species (Juniperus virginiana, Juniperus occidentalis, and Juniperus ashei) against four species of wood-rot fungi (Gloeophyllum trabeum, Postia placenta, Trametes versicolor, Irpex lacteus). It was found that the hexane extracts had lower antifungal activity than the ethanol extracts, and the extracts of juniper were more effective especially against white-rot fungi compared to brown-rot fungi. Özgenç et al. (2017) reported that extracts of some wood barks including Pinus pinaster L., Casuarina eq- uisetifolia L., Acacia mollissima L., Pinus brutia Ten., Abies nordmanniana showed strong antifungal activity against brown-rot fungus; Coniophora puteana, and white-rot fungus; Trametes versicolor. They also indicated that antifungal activity rate showed an increase with increasing the concentration of bark extract solutions. Hosseinihashemi et al. (2015) investigated the antioxidant and antifungal properties of heartwood, bark and leaf of different fractions of Robinia pseudoacacia, and they reported that ethyl acetate fraction of bark extract showed the highest antifungal activity against wood-rot fungi Trametes versicolor.

\subsection{Total polyphenol content and antioxidant activity}

3.2. Ukupni sadržaj polifenola i antioksidativno djelovanje

Results of total polyphenol content (TPC, TFC, CTC) and antioxidant activity (FRAP) of ethanol and methanol extracts of the parts of date plum, loquat and olive trees are given in Table 4.

As can be seen in Table 4, the highest TPC value was determined for methanol extract of loquat bark with $14.998 \mathrm{mg} \mathrm{GAE} / \mathrm{g}$ and the lowest for ethanol extract of olive tree sapwood with $0.543 \mathrm{mg}$ GAE/g. Among all methanol and ethanol extracts obtained from different parts of three fruit trees, it was found that the ethanol extracts of barks of date plum trees with $8.866 \mathrm{mg} \mathrm{GAE} / \mathrm{g}$ and ethanol extracts of loquat bark with $8.494 \mathrm{mg}$ GAE/g had high TPC values. Y1ldiz et al. (2018) reported that the bark of Acacia dealbata had the highest total phenolic content. Ateş et al. (2015) determined TPC values as the antioxidant activities of heartwood and sapwood of juniper (Juniperus foetidissima) and olive (Olea europaea var. sylvestris). They reported that the highest TPC value was obtained from methanol extract of Juniperus foetidissima heartwood. In another study, Hamad et al. (2019) reported that the total phenolic content of bark extractives of oak and beech was $48 \mathrm{mg} / \mathrm{g}$ and $42.04 \mathrm{mg} / \mathrm{g}$, respectively. Gao et al. (2007) investigated the antioxidant activity of methanol extract of sapwood, heartwood, and inner and outer bark of Port Orford cedar. The highest TPC value was detected in the inner bark and the lowest TPC value was observed in the heartwood. In addition, TPC of extracts prepared with different solvents (water, methanol, ethanol, $50 \%$ ethanol, $50 \%$ methanol, $70 \%$ acetone) of Bridelia retusa Spreng. stem bark ranged between 1.6-7.6 mg GAE (Tatiya et al., 2011).

As seen in Table 4, the total flavonoid content values were not found in sapwood and heartwood of fruit trees, while TFC values were only found in barks of all studied trees except for ethanol extract of date plum tree and methanol extract of olive tree. The highest TFC was calculated in methanol extract of loquat bark as $0.173 \mathrm{mg} \mathrm{QE} / \mathrm{g}$. However, in this study, TFC values were found lower than the results reported in the literature due to the low concentration of the prepared solvent. Ateş et al. (2015) investigated TFC values for both heartwood and sapwood of juniper and olive. According to their results, the lowest TFC was found for 
Table 4 Total polyphenol content and antioxidant activity of ethanol and methanol extracts of parts of date plum, loquat and olive trees

Tablica 4. Ukupni sadržaj polifenola i antioksidativno djelovanje ekstrakta u etanolu i metanolu iz dijelova drva draguna, nušpule i masline

\begin{tabular}{|c|c|c|c|c|c|c|}
\hline $\begin{array}{c}\text { Sample } \\
\text { Uzorak }\end{array}$ & $\begin{array}{l}\text { Part of tree } \\
\text { Dio drva }\end{array}$ & $\begin{array}{l}\text { Solvent } \\
\text { Otapalo }\end{array}$ & $\begin{array}{c}\text { TPC } \\
\mathrm{mg} \mathrm{GAE} / \mathrm{g}\end{array}$ & $\begin{array}{c}\text { TFC } \\
\mathrm{mg} \mathrm{QE} / \mathrm{g}\end{array}$ & $\begin{array}{c}\text { CTC } \\
\mathrm{mg} \mathrm{CE} / \mathrm{g}\end{array}$ & $\begin{array}{c}\text { FRAP } \\
\mu \mathrm{molFeSO}_{4} 7 \mathrm{H}_{2} \mathrm{O} / \mathrm{g}\end{array}$ \\
\hline \multirow{6}{*}{$\begin{array}{l}\text { Date plum } \\
\text { dragun }\end{array}$} & \multirow{2}{*}{$\begin{array}{l}\text { Sapwood } \\
\text { bjeljika }\end{array}$} & $\mathrm{E}$ & $1.282(0.091)^{\mathrm{ab}}$ & - & - & $60.134(1.344)^{\mathrm{c}}$ \\
\hline & & M & $3.789(0.005)^{\mathrm{d}}$ & - & - & $67.475(0.122)^{\mathrm{e}}$ \\
\hline & \multirow{2}{*}{$\begin{array}{l}\text { Heartwood } \\
s r z ̌\end{array}$} & $\mathrm{E}$ & $1.139(0.001)^{\mathrm{ab}}$ & - & $0.048(0.001)^{\mathrm{a}}$ & $58.673(0.296)^{\mathrm{c}}$ \\
\hline & & $\mathrm{M}$ & $3.413(0.017)^{\mathrm{cd}}$ & - & $0.275(0.001)^{b}$ & $88.233(1.222)^{\mathrm{f}}$ \\
\hline & \multirow{2}{*}{$\begin{array}{l}\text { Bark } \\
\text { kora }\end{array}$} & $\mathrm{E}$ & $8.866(0.406)^{f}$ & - & - & $230.376(6.166)^{\mathrm{k}}$ \\
\hline & & $\mathrm{M}$ & $3.518(0.003)^{\mathrm{cd}}$ & $0.0002(0.001)^{\mathrm{a}}$ & $0.131(0.001)^{\mathrm{a}}$ & $158.890(0.655)^{1}$ \\
\hline \multirow{6}{*}{$\begin{array}{l}\text { Loquat } \\
\text { nušpula }\end{array}$} & \multirow{2}{*}{$\begin{array}{l}\text { Sapwood } \\
\text { bjeljika }\end{array}$} & $\Gamma$ & 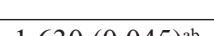 & & & 62106 (1 270)cd \\
\hline & & E & $1.630(0.045)^{\mathrm{ab}}$ & - & - & $\frac{62.186(1.279)^{\mathrm{ca}}}{58.130(2.302)^{\mathrm{c}}}$ \\
\hline & \multirow{2}{*}{$\begin{array}{l}\text { Heartwood } \\
s r z ̌\end{array}$} & $\frac{\mathrm{N} 1}{\mathrm{E}}$ & $\frac{2.440(0.015)^{\mathrm{e}}}{5.264(0.056)^{\mathrm{e}}}$ & $\begin{array}{l}- \\
-\end{array}$ & $2.946(0.031)^{\mathrm{d}}$ & $\frac{50.450(2.392)}{97.994(3.925)^{\mathrm{g}}}$ \\
\hline & & $\mathrm{M}$ & $6.366(2.981)^{\mathrm{e}}$ & - & $4.401(0.018)^{\mathrm{e}}$ & $122.141(0.698)^{\mathrm{h}}$ \\
\hline & \multirow{2}{*}{$\begin{array}{l}\text { Bark } \\
\text { kora }\end{array}$} & $\mathrm{E}$ & $8.494(0.478)^{\mathrm{f}}$ & $0.0003(0.000)^{\mathrm{a}}$ & $6.815(0.060)^{\mathrm{f}}$ & $307.791(0.531)^{\mathrm{m}}$ \\
\hline & & M & $14.998(0.061)^{\mathrm{g}}$ & $0.173(0.001)^{\mathrm{c}}$ & $7.703(0.292)^{g}$ & $299.251(5.987)^{1}$ \\
\hline & & & & & & \\
\hline \multirow{6}{*}{$\begin{array}{l}\text { Olive } \\
\text { maslina }\end{array}$} & \multirow{2}{*}{$\begin{array}{l}\text { Sapwood } \\
\text { bjeljika }\end{array}$} & $\mathrm{E}$ & $0.543(0.008)^{\mathrm{a}}$ & - & - & $43.522(0.009)^{\mathrm{b}}$ \\
\hline & & $\mathrm{M}$ & $1.647(0.001)^{\mathrm{ab}}$ & - & $0.269(0.005)^{b}$ & $66.032(0.887)^{\mathrm{de}}$ \\
\hline & \multirow{2}{*}{$\begin{array}{l}\text { Heartwood } \\
s r z ̌\end{array}$} & $\mathrm{E}$ & $0.774(0.002)^{\mathrm{a}}$ & - & - & $45.276(0.089)^{\mathrm{b}}$ \\
\hline & & $\mathrm{M}$ & $1.352(0.185)^{\mathrm{ab}}$ & - & - & $90.075(0.311)^{\mathrm{f}}$ \\
\hline & \multirow{2}{*}{\begin{tabular}{|l|} 
Bark \\
kora
\end{tabular}} & $\mathrm{E}$ & $1.202(0.081)^{\mathrm{ab}}$ & $0.018(0.000)^{b}$ & $0.301(0.027)^{b}$ & $31.310(0.789)^{\mathrm{a}}$ \\
\hline & & $\mathrm{M}$ & $0.616(0.004)^{\mathrm{a}}$ & - & $1.132(0.001)^{c}$ & $59.283(0.512)^{\mathrm{c}}$ \\
\hline
\end{tabular}

TPC - total phenolic content, TFC - total flavonoid content, CTC - condensed tannin content, FRAP - ferric reducing antioxidant power, E ethanol, $\mathrm{M}$ - methanol. Values in parenthesis are standard deviations. Different superscript letters in the same column indicate significant difference by Duncan's homogeneity test, $P \leq 0.05$. / TPC-ukupni sadržaj fenola, TFC-ukupni sadržaj flavonoida, CTC-sadržaj kondenziranog tanina, FRAP - redukcijska antioksidativna snaga željeza, E-etanol, M-metanol. Vrijednosti u zagradama standardne su devijacije. Različita

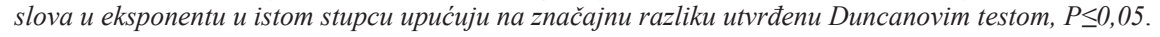

methanol extract of olive heartwood, while the highest TFC was found for ethanol extract of olive sapwood.

Results of samples of the condensed tannin content (CTC) are presented in Table 4. According to these results, it can be concluded that the methanol extracts of loquat bark had the highest CTC value (7.703 mg CE/g), and the second highest CTC value (6.815 mg CE/g) was determined in ethanol extract of loquat bark. In this study, CTC values of methanol extracts of studied tree samples were found higher than those of ethanol extracts. In a study performed by Yildiz et. al (2018), the condensed tannin content of methanol extracts of sapwood, heartwood and bark of Acacia dealbata was determined as $0.620,4.473,4.789 \mathrm{mg} \mathrm{CE} / \mathrm{g}$, respectively.

FRAP, used in this study, is one of the most widely used antioxidant methods. FRAP activities of the studied methanol and ethanol extracts ranged between 31.310 and $307.791 \mu \mathrm{mol} \mathrm{FeSO}_{4} 7 \mathrm{H}_{2} \mathrm{O} / \mathrm{g}$. While the ethanol extract of loquat bark had the highest antioxidant activity, the ethanol extract of olive bark had the lowest antioxidant activity. Comparing FRAP values for different parts of three fruit trees, it was seen that especially heartwood and bark of loquat tree showed higher values than those of date plum and olive tree. According to the results of One-Way ANOVA test, there were statistically significant differences $(P \leq 0.05)$ among experimental groups for TPC, TFC, CTC, FRAP. Furthermore, taking into consideration all the results (TPC, TFC, CTC, FRAP), it can be concluded that, generally, ethanol and methanol extracts of bark and heartwood of loquat had higher values. Some different trends between our results and other results reported in the literature can likely be attributed to various parameters such as different concentration and extraction methods, environmental factors, etc. Based on these results, it was found that all the studied trees have more or less potential to be evaluated as antioxidant and antifungal activity source. Therefore, it is recommended that their potentials can be increased by trying high concentrations and different methods.

\section{CONCLUSIONS \\ 4. ZAKLJUČAK}

Important findings of this comparative study carried out for three fruit trees can be summarized as follows:

Generally, essential oil of all fruit trees inhibited the fungal growth rate of $C$. puteana.

All studied hot water extracts and hydrosols showed no antifungal activity against $C$. puteana.

Olive tree showed higher antifungal activity compared to loquat and date plum trees.

The highest total phenolic content (TPC), total flavonoid content (TFC), condensed tannin content (CTC) and antioxidant activity (FRAP) were found in ethanol and methanol extracts of bark and heartwood of loquat. The highest TPC, TFC and CTC were observed in methanol extract of loquat bark. 


\section{Acknowledgements - Zahvala}

Authors gratefully thank Professor Sibel YILDIZ and Res. Assist. Ayşenur GÜRGEN for their support and suggestions.

\section{REFERENCES}

\section{LITERATURA}

1. Ateş, S.; Gür, M.; Özkan, O. E.; Akça, M.; Olgun, Ç.; Güder, A., 2015: Chemical contents and antifungal activity of some durable wood extractives vs. Pleurotus ostreatus. BioResources, 10(2): 2433-2443.

2. Benzie, I. F. F.; Strain, J. J., 1996: The ferric reducing ability of plasma (FRAP) as a measure of "antioxidant power": the FRAP assay. Analytical Biochemistry, 239: 70-76. https://doi.org/10.1006/abio.1996.0292.

3. Clevenger, J. F., 1928: Apparatus for the determination of volatile oil. Journal of the American Pharmacists Association, 17: 341-346.

4. Fidah, A.; Salhi, N.; Rahouti, M.; Kabouchi, B.; Ziani, M.; Aberchane, M.; Famiri, A., 2016: Natural durability of Cedrus atlantica wood related to the bioactivity of its essential oil against wood decaying fungi. Maderas: Ciencia y Tecnología., 18: 567-576. http://dx.doi.org/10.4067/S0718-221X2016005000049.

5. Fukumoto, L. R.; Mazza, G., 2000: Assessing antioxidant and prooxidant activities of phenolic compounds. Journal of Agricultural and Food Chemistry, 48: 3597 3604. https://doi.org/10.1021/jf000220w.

6. Gao, H.; Shupe, T. F.; Eberhardt, T. L.; Hse, C. Y., 2007 Antioxidant activity of extracts from the wood and bark of Port Orford cedar. Journal of Wood Science, 53(2): 147-152. https://doi.org/10.1007/s10086-006-0850-z

7. Gao, H.; Cheng, N.; Zhou, J.; Wang, B.; Deng, J.; Cao, W., 2014: Antioxidant activities and phenolic compounds of date plum persimmon (Diospyros lotus L.) fruits. Journal of Food Science and Technology, 51: 950-956. https://doi.org/10.1007/s13197-011-0591-x.

8. Ghanbari, R.; Anwar, F.; Alkharfy, K. M.; Gilani, A. H.; Saari, N., 2012: Valuable nutrients and functional bioactives in different parts of olive (Olea europaea L.) - A review. International Journal of Molecular Sciences, 13 3291-3340. https://doi.org/10.3390/ijms13033291.

9. Hamad, A. M. A.; Ates, S.; Olgun, C..; Gur, M., 2019: Chemical Composition and Antioxidant Properties of Some Industrial Tree Bark Extracts. BioResources, 14(3): 5657-5671.

10. Hosseinihashemi, S. K.; HosseinAshrafi, S. K.; Goldeh, A. J.; Salem, M. Z. M., 2015: Antifungal and antioxidant activities of heartwood, bark, and leaf extracts of Robinia pseudoacacia. BioResources, 11: 1634-1646.

11. Julkunen-Tiitto, R., 1985: Phenolic constituents in the leaves of northern willows: methods for the analysis of certain phenolics. Journal of Agricultural and Food Chemistry, 33: 213-217. https://doi.org/10.1021/jf00062a013.

12. Liu, Y.; Zhang, W.; Xu, C.; Li, X., 2016: Biological activities of extracts from loquat (Eriobotrya japonica Lindl.): A Review. International Journal of Molecular Sciences, 17(12):

13. Mamıkoğlu, N. G., 2007: Türkiye'nin ağaçları ve çalıları: NTV Publishing, İstanbul (in Turkish).

14. Mihara, R.; Barry, K. M.; Mohammed, C. L.; Mitsunaga, T., 2005: Comparison of antifungal and antioxidant activities of Acacia mangium and A. auriculiformis heartwood extracts. Journal of Chemical Ecology, 31(4): 789804. https://doi.org/10.1007/s10886-005-3544-x
15. Noroozi, J.; Zare, G.; Sherafati, M.; Mahmoodi, M.; Moser, D; Asgarpour, Z.; Schneeweiss, G. M., 2019: Patterns of endemism in Turkey, the meeting point of three global biodiversity hotspots, based on three diverse families of vascular plants. Frontiers in Ecology and Evolution, 7, 159. https://doi.org/10.3389/fevo.2019.00159.

16. Özgenç, Ö.; Durmaz, S.; Yıldız, Ü. C.; Erişir, E., 2017: Comparison Between Some Wood Bark Extracts: Antifungal Activity. Kastamonu University Journal of Forestry Faculty, 17: 502-508. https://doi.org/10.17475/kastorman.282637.

17. Rauf, A.; Uddin, G.; Khan, H.; Raza, M.; Zafar, M.; Tokuda, H., 2016: Anti-tumour-promoting and thermalinduced protein denaturation inhibitory activities of $\beta$-sitosterol and lupeol isolated from Diospyros lotus L. Natural Product Research, 30: 1205-1207. https://doi.org/10.1080/14786419.2015.1046381.

18. Singh, J.; Tripathi, N. N., 1999: Inhibition of storage fungi of blackgram (Vigna mungo L.) by some essential oils. Flavour and Fragrance Journal, 14: 1-4. https://doi. org/10.1002/(sici)1099-1026(199901/02)14:1<1::aidffj735>3.0.co;2-r.

19. Slinkard, K.; Singleton, V. L., 1977: Total phenol analysis: automation and comparison with manual methods. American Journal of Enology and Viticulture. 28: 49-55.

20. Tatiya, A. U.; Tapadiya, G. G.; Kotecha, S.; Surana, S. J., 2011: Effect of solvents on total phenolics, antioxidant and antimicrobial properties of Bridelia retusa Spreng. stem bark. Indian Journal of Natural Products and Resources, 2: 442-447.

21. Topaloğlu, E.; Öztürk, M.; Ustaömer, D.; Serdar, B., 2019: Wood anatomy properties of some fruit trees in the Eastern Black Sea Region and their evaluation in terms of paper production. Turkish Journal of Forestry Research, 6(2): 142-151. (in Turkish).

22. Tümen, I.; Eller, F. J.; Clausen, C. A.; Teel, J. A., 2013: Antifungal activity of heartwood extracts from three Juniperus species. BioResources, 8(1): 12-20.

23. Uddin, G.; Rauf, A.; Siddiqui, B. S.; Arfan, M.; Rahman, U. I.; Khan, I., 2013: Proximate chemical composition and antimicrobial activities of fixed oils from Diospyros lotus. L. Medicinal Chemistry, 3: 282-285. http://dx.doi.org/10.4172/2161-0444.1000152.

24. Uddin, G.; Rauf, A.; Siddiqui, B. S.; Muhammad, N.; Khan, A.; Shah, S. U. A., 2014: Anti-nociceptive, antiinflammatory and sedative activities of the extracts and chemical constituents of Diospyros lotus L. International Journal of Phytotherapy and Phytopharmacology, 21: 954-959. https://doi.org/10.1016/j.phymed.2014.03.001.

25. Yıldız, S.; Gürgen, A.; Can, Z.; Tabbouche, S. A.; Kılıç, A. O., 2018: Some bioactive properties of Acacia dealbata extracts and their potential utilization in wood protection. Drewno, 61: 81-97. https://doi.org/10.12841/wood.1644-3985.255.03

26. Zhang, Z. P.; Ma, J.; He, Y. Y.; Lu, J.; Ren, D. F., 2018 : Antioxidant and hypoglycemic effects of Diospyros lotus fruit fermented with Microbacterium flavum and Lactobacillus plantarum. Journal of Bioscience and Bioengineering, 125: 682-687. https://doi.org/10.1016/j.jbiosc.2018.01.005.

27. ${ }^{* * * C A B I}$, 2019a: Olea europaea subsp. europaea (European olive). In: Invasive Species Compendium. Wallingford, UK: CAB International, www.cabi.org/isc (Accessed Mar. 20, 2019).

28. ***CABI, 2019b: Eriobotrya japonica (loquat). In: Invasive Species Compendium. Wallingford, UK: CAB International, www.cabi.org/isc (Accessed Mar. 20, 2019). 
.. Ustaömer, Topaloğlu, Yilmaz, Serencam, Deniz: An in Vitro Study on Antifungal Properties...

29. ***FAO, 2018: Biodiversity of Turkey. Contribution of Genetic Resources to Sustainable Agriculture and Food Systems. Ankara. 222 p. www.fao.org/3/ca1517en/ CA1517EN.pdf (Accessed Nov. 11, 2019).

30. ***TÜİK, 2018a: Turkish Statistical Institute, www. tuik.gov.tr/PreTablo.do?alt_id=1001. (Accessed March 13, 2019).

31. ***TÜIK, 2018: Turkish Statistical Institute, Olive production, 1988-2018, www.tuik.gov.tr/PreTablo.do?alt id=1001. (Accessed March 13, 2019).

32. ***TÜİK, 2018c: Turkish Statistical Institute, Pome fruits, 1988-2018 www.tuik.gov.tr/PreTablo.do?alt $\mathrm{id}=1001$. (Accessed March 13, 2019).

\section{Corresponding address:}

\section{BILGE YILMAZ}

Karadeniz Technical University

Faculty of Forestry

Forest Industrial Engineering

Trabzon 61080, TURKEY

e-mail: bilgekarasakal@gmail.com 